\title{
TERAPI MUSIK KLASIK PADA IBU HAMIL UNTUK MENURUNKAN \\ KECEMASAN MENJELANG PROSES PERSALINAN DI BPM HJ.DINCE \\ SAFRINA, SST
}

Rita Afni

STIKes Hang Tuah Pekanbaru,

Rita.afni@htp.ac.id

\begin{abstract}
Abstrak
Ibu hamil trimester 3 yang sedang menanti pross persalinan, terkadang menimbulkan beberapa gangguan psikologis yang dapat mengganggu proses persalinan. Salah satu bentuk gangguan psikologis selama tahap ini adalah timbulnya rasa cemas, perasaan yang berubah-ubah, gangguan tidur hingga gangguan pada sitem pencernaan. Beberapa hal yang dapat dilakukan untuk mencegah dan mengurangi terjadinya gangguan psikologis yang ditandai dengan adanya kecemasan dan kurangnya rasa nyaman ibu hamil menjelang persalinan salah satunya adalah dengan terapi musik klasik. Terapi musik klasik dilakukan dengan tujuan untuk mengurangi tingkat kecemasan pada ibu hamil dan memberikan rasa nyaman. Terapi ini dilakukan dengan memutarkan berbagai macam musik klasik pada ibu hamil. Hasil setelah dilakukan terapi musik klasik didapati hasil keluhan ibu yang berkurang dan ibu merasa lebih nyaman saat tidur . Kesimpulannya dengan pemberian terapi musik klasik ini dapat menurunkan tingkat kecemasan pada ibu hamil menjelang proses persalinan. Disarankan pada kepada penyedia layanan kesehatan dapat mengadakan penyuluhan maupun menerapkan terapi musik klasik pada kelas ibu hamil sehingga dapat mencegah adanya kecemasan selama masa hamil menjelang proses persalinan.

Kata kunci

: Ibu hamil trimester 3, Kecemasan, Terapi musik klasik
\end{abstract}

\section{Abstract}

Pregnat woman trimester 3 who waiting to deliver her baby, sometimes have a disturbance of the psychology that can distrub the labor. One of disturbance of psychology belong of this level is anciety, wishy washy, insomnsia until indigestion. Something that can to do for prevent and reduce disturbance of the psychology effect is with classical music therapy. Therapy of classical music aiming for reduce the anxiety and incrase the convenience the patient for waiting to deliver her baby. This therapy is doing by playing some type of classical music for patient. The result of this therapy is reduce the anxiety of patient and increase the convenience. The conclusion is with therapy of classical music for pregnant woman can reduce the anxiety and incrase the convenience patient for deliver her baby. Suggested for all the independent widwife practice can to apply this therpay for all pregnat woman TM3 to prevent the anxiety belong her labor.

Keywords : Pregnant woman TM3, Anxiety, Therapy of music classic 


\section{PENDAHULUAN}

Kehamilan normal biasanya berlangsung kira-kira 10 bulan lunar atau 9 bulan kalender, atau 40 minggu atau 280 hari . Lamanya kehamilan dihitung dari pertama menstruasi terakhir (Kusmiyati, 2009). Setelah fase kehamilan seorang Ibu hamil akan memasuki fase persalinan. Persalinan adalah proses pengeluaran hasil konsepsi yang cukup bulan dan mampu bertahan diluar kandungan melalui jalan lahir dengan bantuan maupun tanpa bantuan (Ilmiah, 2014).

Pada waktu seorang ibu hamil menjelang proses persalinan, kerap kali menimbulkan beberapa gangguan psikologis yang dapat mengganggu proses persalinan. Salah satu bentuk gangguan psikologis selama tahap ini adalah timbulnya rasa cemas, khawatir hingga depresi yang dapat menyebabkan hilangnya kenyamanan dalam diri ibu menjelang proses persalinan. Faktor penyebab timbulnya rasa cemas berhubungan dengan rasa aman dan nyaman, penemuan jati diri dan persiapan menjadi orang tua, sikap memberi dan menerima kehamilan, keuangan, support keluarga dan support tenaga medis (Janiwarty, 2012).

Dampak buruk dari rasa cemas dan khawatir yang diderita oleh wanita hamil tersebut dapat menimbulkan gangguan perkembangan dan pertumbuhan janin dan gangguan kesehatan mental anak nantinya. Seorang anak yang dilahirkan ibu yang mengalami depresi berat selama kehamilan akan memiliki kadar hormon stress tinggi, aktifitas otak akan peka terhadap depresi, menunjukkan sedikit ekspresi, mengalami gejala depresi lain, sulit makan dan tidur. Jika depresi pada bayi baru lahir tidak segera ditangani, anak berkembang menjadi anak yang tidak bahagia. Mereka sulit berjalan berat badan kurang dan tidak responsif terhadap orang lain. Semua yang difikirkan ibu pada saat hamil akan tersalurkan melalui hormon syaraf ke bayinya sehingga dapat menyebakan kelahiran prematur, hiperaktif, dan mudah marah (Janiwarty, 2012).

Beberapa hal yang dapat dilakukan untuk mencegah terjadinya gangguan psikologis yang ditandai dengan adanya kecemasan dan kurangnya rasa nyaman ibu hamil menjelang persalinan salah satu tindakan yang dapat dilakukan adalah terapi. Tindakan terapi yang biasanya dilakukan dengan hipnoterapi untuk mengurangi tingkat kecemasan pada ibu hamil. Namun, dalam pelaksanaannya hipnoterapi masih terbilang sulit atau tidak bisa dilakukan sendiri pada ibu hamil (Geraldina, 2017). Terapi musik merupakan terapi yang dilakukan menggunakan musik dan aktivitas musik untuk memfasilitasi proses terapi dalam membantu kliennya. Sebagaimana halnya terapi yang merupakan upaya yang dirancang untuk membantu orang dalam konteks fisik dan mental, terapi musik mendorong klien untuk berinteraksi, improvisasi, mendengarkan atau aktif bermain musik (Geraldina, 2017).

Selama ini terapi musik banyak digunakan untuk mengatasi berbagai permasalahan seperti untuk menurunkan stres dan menurunkan kecemasan pada pasien 
yang akan menjalani pengobatan. Terapi musik klasik efektif untuk mengurangi kecemasan pada ibu hamil resiko tinggi. Dalam sebuah penilitian didapati hasil bahwa terapi musik klasik efektif untuk menurunkan kecemasan pada ibu hamil menjelang persalinan dengan $\mathrm{p}$ value $0.001(\mathrm{p}<0.05)$ (Asmara.dkk, 2017).

Tujuan pelaksanaan asuhan ini adalah melakukan asuhan kebidanan pada ibu hamil dengan pemberian terapi musik klasik untuk meningkatkan kenyamanan menjelang persalinan.

\section{METODE}

Metode yang digunakan adalah studi kasus dengan mengacu pada asuhan kebidanan pada ibu hamil yang sudah memasuki Trimester 3. Studi kasus ini menggambarkan asuhan kebidanan yang diberikan pada ibu hamil primigravida trimester 3 dengan terapi musik klasik untuk mengurangi kecemasan menjelang proses persalinan.

\section{HASIL}

\section{a) Kunjungan Pertama}

Kajian pertama dilakukan pada Ny. M pada tanggal 21 Juli 2019, kunjungan antenatal dilakukan di BPM Dince Safrina. data subjektif Ny. M usia 25 tahun, Ibu ingin melakukan pemeriksaan kehamilan, dan ibu mengatakan takut menghadapi persalinan serta belum siap utk menghadapi persalinan yang semakin dekat. Seperti yang dikatakan ibu "Perasaan saya sering berubah ubah, terkadang saya merasa siap untuk melahirkan dan perasaan sebagai orang tua namun dimalam hari perasaan saya kembali berubah menjadi gelisah dan merasa tidak siap terhadap persalinan, saya merasa mendapat dukungan di tempat kerja, sedangkan ketika dirumah saya merasa kesepian dan sendiri karena suami yang pulang bekerja pada malam hari dan saya sulit untuk tertidur, dan mudah terbangun dari tidur ketika malam hari" Ibu mengatakan istirahat siang 30 menit dan tidur malam 5-6 jam. Riwayat kesehatan ibu tidak ada terkena penyakit serius dan tidak ada keturunan penyakit lain.

Pada pengumpulan data objektif ditemukan Keadaan umum ibu baik, tekanan darah 110/80 mmHg, denyut nadi 80 $\mathrm{x} /$ menit, pernafasan $22 \mathrm{x} /$ menit, suhu 36,6 ${ }^{\circ} \mathrm{C}$, kelopak mata ibu tidak pucat, konjungtiva merah muda, sklera putih, pada mammae puting susu menonjol, ibu tidak ada merasakan benjolan maupun rasa nyeri, kebersihan baik. Tinggi fundus uteri pertengahan $1 / 2$ pusat-px. Bagian atas perut ibu teraba bokong janin, dan pada bagian bawah perut ibu teraba kepala janin. Mc. Donald $29 \mathrm{~cm}$. TBBJ 2480 gr. Denyut jantung janin teratur dengan frekuensi 140x/menit. Refleks patella positif.

Melakukan asuhan terapi musik klasik pada ibu. Pemberian terapi dilakukan selama 7 menit dengan posisi ibu berbaring di tempat tidur. Selama pemberian musik klasik ajarkan ibu relaksasi dengan cara menarik nafas panjang dan hembuskan perlahan lewat mulut. Anjurkan kepada ibu dan keluarga untuk meakukan terapi musik klasik dengan 
cara serupa setiap dirumah selama 1 minggu. Anjurkan peran serta keluarga untuk membantu ibu relaksasi.

\section{b) Kunjungan Kedua}

Kajian kedua dilakukan pada Ny.M pada tanggal 27 Juli 2019 bertempat dirumah pasien. Ibu sudah melakukan terapi musik klasik selama 1 minggu pada malam hari yang dibantu oleh suami. Terapi yang sudah dilakukan selama 1 minggu dengan durasi 7 menit disetiap terapi, membawa perubahan dan perkembangan pada keluhan ibu dikunjungan sebelumnya. Seperti yang dikatakan ibu "saya merasa tidur sedikit lebih nyenyak dan mudah untuk tidur, saya merasa senang karena suami ikut serta dalam pemberian terapi musik klasik disetiap malam dan saya merasa senang karena suami memberikan dukungan pada saya saat melakukan terapi ini"

Pada pengumpulan data obejektif ditemukan keadaan umum ibu baik, tekanan darah ibu $110 / 70 \mathrm{mmHg}$, nadi $81 \mathrm{x} / \mathrm{menit}$, pernafasan $21 \mathrm{x} /$ menit, suhu $36,5^{\circ} \mathrm{C}$, detak jantung janin 145x/menit

\section{PEMBAHASAN}

Dari hasil anamnesis didapatkan bahwa ibu mengatakan sulit untuk tertidur dan sering terbangun saat tidur malam yang menyebabkan berkurangnya durasi ibu beristirahat dimalam hari. Hormon serotonin yang mengakibatkan stress pada ibu hamil, serotonin berinteraksi dengan dopamin dan kortisol yang meningkatkan produksi dopamin dan menghambat produksi kortisol sehingga ibu mengalami peningkatan stress yang mengakibatkan insomnia pada ibu hamil dan terjadi peningkatan kadar progesteron dan esterogen. Progesteron dapat menurunkan kualitas tidur, esterogen dapat menyebabkan edema mukosa saluran nafas bagian atas (Pratama, 2017).

Kunjungan pertama dilakukan pemberian edukasi dan informasi mengenai keluhan ibu dan mengenai terapi musik klasik yang akan dilakukan pada pasien. Pada pemberian terapi musik klasik yang dilakukan turut melibatkan keluarga terutama suami, dikarenakan dukungan keluarga dapat memberikan efek yang lebih signifikan pada terapi yang dilakukan. Berdasarkan teori yang menyebutkan bahwa terdapat beberapa faktor yang dapat mempengaruhi perubahan psikologis dan perkembangan pemberian terapi yakni faktor internal dan faktor eksternal yang salah satunya adalah dukungan suami dan keluarga.

Pada kunjungan kedua penulis melakukan penilaian dan perkembangan kondisi serta keluhan ibu dari kunjungan pertama. Hasil yang diperoleh dari anamnesis pasien dikunjungan kedua ini adalah ibu mengatakan bahwa keluhan ibu berkurang, ditandai dengan ibu merasa lebih relaks dan mudah untuk tidur dimalam hari serta ibu merasa lebih senang atas keterlibatan suami dalam melakukan terapi musik klasik. Pemberian terapi musik klasik efektif untuk mengurangi kecemasan pada ibu hamil resiko tinggi serta efektif untuk menurunkan kecemasan pada ibu hamil menjelang persalinan. 


\section{KESIMPULAN}

Penatalaksanaan yang dilakukan adalah dengan memberikan edukasi dan informasi mengenai terapi musik klasik dan melakuan pemeriksaan kebidanan secara menyeluruh pada ibu hamil yang disertai dengan pemberian terapi musik klasik selama 1 minggu dengan durasi 7 menit disetiap kali terapi yang dilakukan setiap malam hari dikarenakan suasana yang tenang dan dapat merelaksikan ibu untuk tidur. Pemberian terapi musik klasik yang telah selama 1 minggu mendapatkan hasil yang cukup meringankan keluhan ibu, ditandai dengan hasil anamnesa dengan pasien mengatakan bahwa ibu tidak lagi terbangun disaat tidur malam, merasa rileks setiap setelah melakukan terapi musik klasik, dan merasa senang atas keterlibatan suami dalam melakukan terapi musik klasik.

\section{DAFTAR PUSTAKA}

Asmara, Maya Shella.dkk. 2017. “Efektifitas

Hipnoterapi dan Terapi Musik Klasik Terhadap Kecemasan Ibu Hamil Resiko Tinggi di Puskesmas Magelang Selatan”. Jurnal Kesehatan

Geraldina, Alma Marikha. 2017. "Terapi Musik: Bebas Budaya atau Terikat Budaya?”. Jurnal Psikologi vol.125.1 (45:53).
Ilmiah, Widia Sari. Buku Ajar Asuhan Persalinan Normal. Jember : Nuha Medika . 2014

Janiwarty,B dan Pieter,H.Z . Pendidikan Psikologi untuk Bidan Suatu Teori dan Terapannya. Medan: Rapha Publishing. 2012

Kusmiyati, Yuni. dkk. Perawatan Ibu Hamil (Asuhan Ibu Hamil). Yogyakarta : Fitramaya . 2009

Pratama, Dicky Alif Heri. 2017. Pengaruh Pregnancy Massage Terhadap Perubahan Kualitas Tidur Ibu Hamil Trimester Ketiga (Studio di Mojo Baby Spa Kec. Maron Kab. Probolinggo) . Skripsi, eprint. Universitas Muhammadiyah Malang. Malang

Rahmitha, Nurul. 2017. Tingkat Kecemasan Pada Ibu Hamil Primigravida Trimester Ketiga di Puskesmas Kecamatan Tamlanrea Makasar. Skripsi. Tidak diterbitkan. Universitas Hasanudin : Makasar

Zahra, Mufidah Az. 2016. Pengaruh Terapi Musik Klasik Mozart dan Terapi Musik Kesukaan Terhadap Tingkat Depresi Mahasiswa Tugas Akhir Fisiologi S1 di Fakultas Ilmu Kesehatan Universitas Muhammadiyah Surakarta. Skripsi. Tidak diterbitkan. Universitas Muhammadiyah : Surakarta 